\title{
防潮堤の設計高を超える津波の挙動に関する数值実験 \\ 一一静岡県松崎および岩手県田老の場合—
}

\author{
(財)地震予知総合研究振興会* 相 田勇 \\ 損害保険料率算定会** 坪 川博 彰・川口正明 \\ (昭和 63 年 5 月 13 日受付; 昭和 63 年 6 月 25 日受理)
}

\section{Numerical Experiments on Behavior of Tsunamis Exceeding the Design Height of a Sea Wall}

\author{
Case Studies for Matsuzaki, Shizuoka Prefecture \\ and Taro, Iwate Prefecture-
}

\author{
Isamu AidA \\ Association for the Development of Earthquake Prediction, Izumi International \\ Enterprise Building 6F, Kanda-Mitoshiro-cho 3, Chiyoda-ku, Tokyo 101 \\ Hiroaki TsuboKawa and Masa'aki Kawaguchi \\ The Fire and Marine Insurance Rating Association of Japan, \\ Kanda-Awaji-cho 2-9, Chiyoda-ku, Tokyo 101 \\ (Received May 13, 1988; Accepted June 25, 1988)
}

\begin{abstract}
The height of a sea wall is usually designed based on water levels of large tsunamis experienced in the past. Behaviors of tsunamis exceeding the design height are examined by means of numerical experiments taking the sea walls at Matsuzaki, Shizuoka prefecture and at Taro, Iwate prefecture. In the case of Matsuzaki, the inundated area reduces to 70 percents of the original one by the presence of the wall although the invasion of tsunami through the river mouth, where no water gate is constructed, is noticeable. In the case of Taro, the sea wall height is designed at 10 meters that equals the height of the 1933 Sanriku tsunami. According to our experiment, however, if a tsunami has the same height as that of the 1933 tsunami, the water level close to the wall front becomes higher than the height of the sea wall. In this case, the water level at some places in the town becomes so high as to give rise to human and material damage in spite of the construction of the sea wall. It is recommended, therefore, that local inhabitants take refuge onto hilltop, unless a small height is predicted by the tsunami warning.
\end{abstract}

\section{§1。はじめに}

近年全国各地の港湾では，海岸に津波対策用としての 何らかの防潮堤が建設されている. その天端の高さは, 過去に経験した津波の高さ，ちるいは想定される津波の 高さなどによって決められているが，次に来襲する津波 が不幸にしてその高さを超える場合が皆無とは言いきれ

昭和 61 年 10 月 9 日および昭和 62 年 10 月 7 日発表

* テ101 千代田区神田美土代町 3 泉国際産業ビル $6 \mathrm{~F}$

** 厂101 千代田区神田淡路町 2-9
ないであろう．また河口，港口などで防潮堤が断たれ， ゲートを設けることが困難な場合は, その部分からの津 波の侵入が避けられない.

このような防潮堤の津波に対する特性，防潮堤による 浸水域の減少，災害防止の効果などに関して，基本的な 調查を行っておくことは，防災上も必要なことである。 岩崎・他 (1981) は, 岩手県綾里を例として, 数値実験に よるこの種の調查を行い, 綾里の防潮堤がチリ津波の高 さに基づいて建設されているため，もし三陸津波と同じ 高さの津波が襲うと，ほぼ 1933 年当時同様な浸水域を 


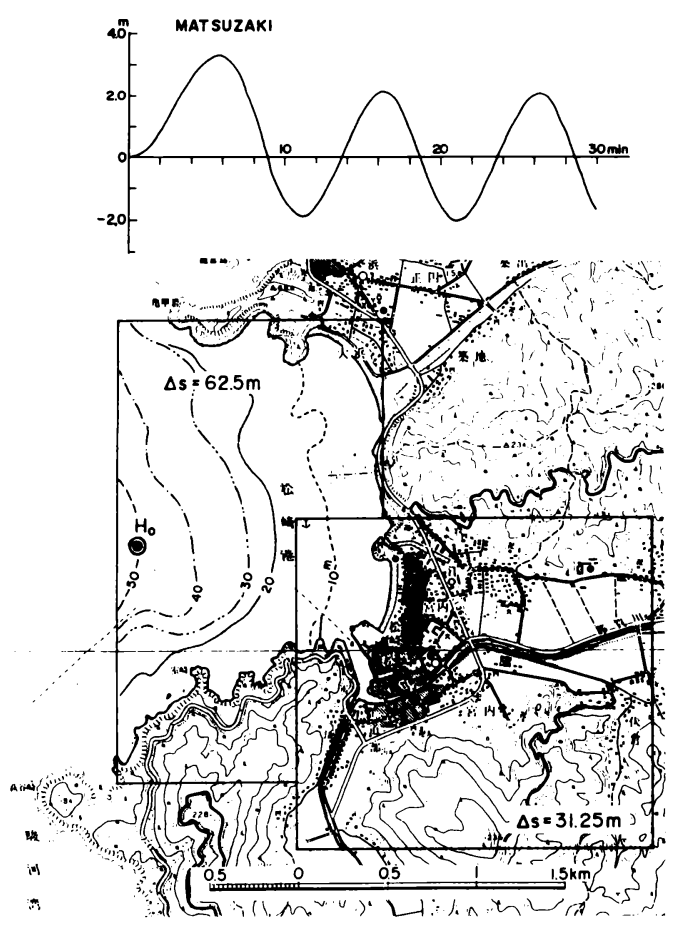

Fig. 1. Map showing the area under computation at Matsuzaki in Shizuoka prefecture and change in the water level with time at point $H_{0}$.

生じると警告している.ここでは, 静岡県松崎町と岩手 県田老町にある防潮堤に関して津波挙動の検討を行っ た.

\section{§ 2. 数値実験の方法}

津波の数值計算は現在さかんに行われており, 方法に 関する吟味もなされている [例えば, 後藤 (1986)].ここ では相田 (1977a)や，相田・羽鳥 (1982)などが行った 遡上数值実験の方法を使用した。 すなわち浅海波方程 式,

$$
\begin{aligned}
\frac{\partial q_{x}}{\partial t}= & -g D \frac{\partial \zeta}{\partial x}-f_{c} \frac{q_{x} Q}{D^{2}} \\
& -\left(\frac{q_{x}}{D} \frac{\partial q_{x}}{\partial x}+\frac{q_{y}}{D} \frac{\partial q_{x}}{\partial y}\right) \\
\frac{\partial q_{y}}{\partial t}= & -g D \frac{\partial \zeta}{\partial y}-f_{c} \frac{q_{y} Q}{D^{2}} \\
& -\left(\frac{q_{x}}{D} \frac{\partial q_{y}}{\partial x}+\frac{q_{y}}{D} \frac{\partial q_{y}}{\partial y}\right) \\
\frac{\partial \zeta}{\partial t}= & -\frac{\partial q_{x}}{\partial x}-\frac{\partial q_{y}}{\partial y}+\frac{\partial \xi}{\partial t}
\end{aligned}
$$

を差分化してリープフロッグ法で解くあのである.ここ

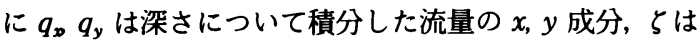

水位上昇, $D=h+\zeta-\xi, h$ は静水面からの水深, $\xi$ は断層 運動による海底の鉛直変位, $f_{c}$ は海底摩擦係数, $Q=$ $\sqrt{q_{x}^{2}+q_{y}^{2}}$ である.

なお $f_{c}$ は陸上域では, 地表面の状况，建物の密集度な どによるエネルギー損失を代表する等価摩擦係数と考 え，後に示すような適宜な値［相田・羽鳥 (1982)］を採 用した。 また防波堤・防潮堤の越流に対しては，本間公 式 [土木学会 (1971)] による越流係数によって流量を計 算した.

\section{§3. 静岡県松崎の婸合}

\section{1 実験 条件}

静岡県松崎は, 伊豆半島南端に近い西岸の港である. 那賀川の河口を利用した港の入口を除いて, 海岸部は高 さ $6 \mathrm{~m}$ （T.P.上）の防潮堤が建設されている．外海での 津波の高さを変えて, 防潮堤内へ侵入する津波の状況を 検討するため, Fig. 1 に示すような範囲の数値計算を 行った。すすなわち港内から陸上部にかけて間隔 $31.25 \mathrm{~m}$ の格子， $61 \times 65$ 個の範囲を遡上計算し，その外側に格 子間隔 $62.5 \mathrm{~m}$ の通常の計算領域を付した．その最も外 側の格子列に, $\eta=A_{0}\left[\exp -3(t / T)^{2}-\cos 2 \pi(t / T)\right]$ で 示される波形の入射津波を与えた。この形は安政東海津 波の数値実験 [相田 (1981)] の結果を参考にして決め, $T$ を 10 分とし， $A_{0}$ は $0.5 \mathrm{~m} \sim 2.0 \mathrm{~m}$ に変化させた. こ の入射波と反射波が重畳した波形を，Fig. 1 の $H_{0}$ 点に ついて図の上部に示した。

また遡上計算領域の詳細は Fig. 2 に示されているが, 陸上部の地形および港内水深は， $1 / 5,000$ 「松崎港平面 図，静岡県」を，また港外水深は水路部の海図 No. 84 を 参照した．図中斜線で影をつけた範囲は家屋が稠密なと ころで $f_{c}=1.0$, 点で影をつけた部分は家屋が柾の部分 で $f_{c}=0.2, \quad$ その他の陸上部は $f_{c}=0.01$, 海底部は $f_{c}=$ 0.005 を与えた。.また $3.2,6$ と数字を付した太線は防波 堤, 防潮堤とその天端高を示す。なお図中のコンターは T.P.を基準にした水深と地表の高さである.

\section{2 結 果}

$H_{0}$ が $3.3 \mathrm{~m}$ および $4.33 \mathrm{~m}$ で, 防潮堤がない場合の浸 水分布を Fig. 3(a) (b) に示した. 図中に示してあるよう に，地上の浸水高 $H_{\mathrm{r}}$ が，(1) $1.5 \mathrm{~m}$ 以上, (2) $0.5 \sim 1.4 \mathrm{~m}$, (3) $0.4 \mathrm{~m}$ 以下の 3 通りに別けて記号で示してある. (1) は家屋の損壊を生じる程度の高さである．Fig. 3(a) に $\mathrm{A}, \mathrm{B}$ で示した点は, 1854 年安政東海津波の際，それぞ れ約 $3.3 \mathrm{~m}$ ，および $3.6 \mathrm{~m}$ の高さになったと推定されて いる [羽鳥 (1977)]. この図の場合の数值実験では, A 点 で $3.4 \mathrm{~m}, \mathrm{~B}$ 点で $3.6 \mathrm{~m}$ 之計算されており, 安政東海津 波の高さとほぼ等しくなっている. しかしその時の浸水 


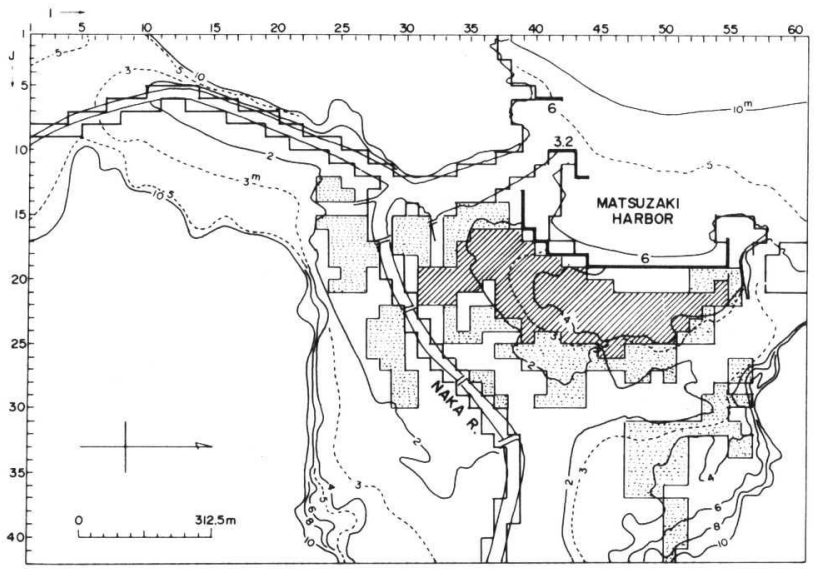

Fig. 2. Details of the inundation model at Matsuzaki. Effective friction coefficients $f_{c}$ are assumed as 1.0 in the hatched area that consists of crowded houses, 0.2 in the dotted area, and 0.01 in other areas, respectively. The sea walls are shown with thick lines to which numerals that indicate their heights are attached.
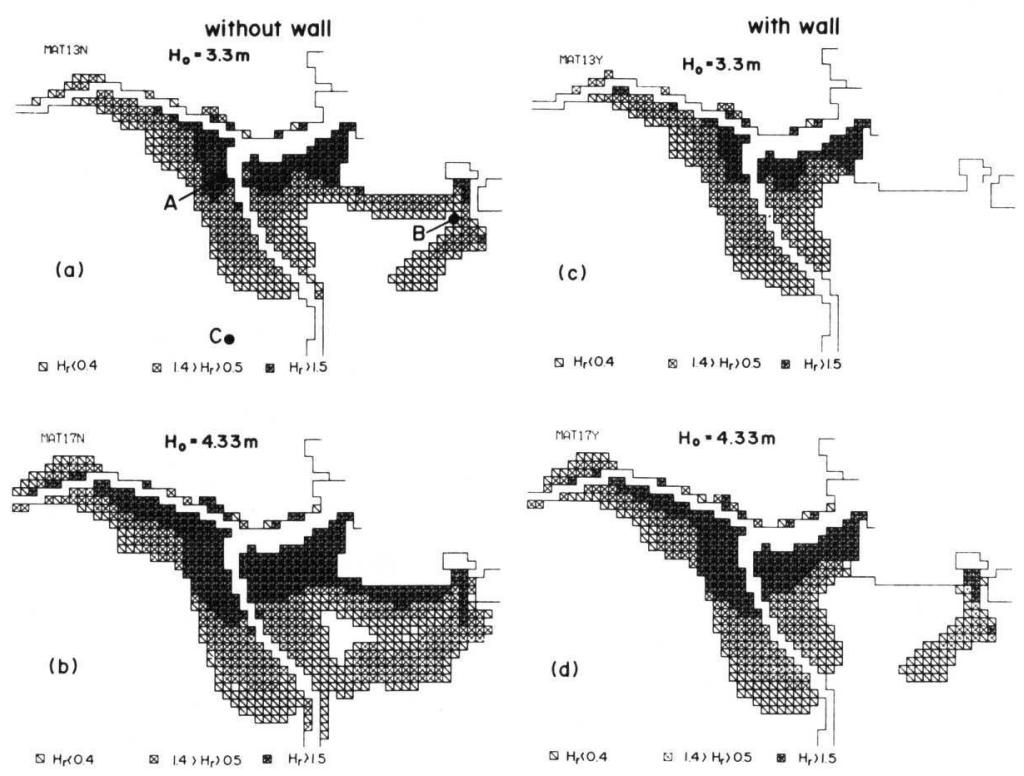

Fig. 3. Inundation area in Matsuzaki as classified by the computed inundation heights above ground, $H_{r}$. (a) (b) and (c) (d) are the results for cases without and with the sea wall, respectively.

域は C 点付近に達していたらしいので, 数値計算の浸水 域の方がやや狭い。これは数値計算が現在の町の家屋密 集状況に基づいているため，陸上奥深く侵入することを 妨げていると考えられる，それを考慮すると，この(a) のケースは安政東海津波を近似しているものと考えてよ いであろう.

この場合の津波の浸水は, 河口からの浸水が大部分で あり, 那賀川沿いに $600 \mathrm{~m}$ 以上屯浸水している. 一方海 岸および北端（図では右端）の小水路からも浸水がある
が, Fig. 2 の地形でみるように, 海岸沿いに標高 $4 \mathrm{~m}$ 以 上の高所があり, その部分およびその背面が浸水を免れ ている. 更に $H_{0}=4.33 \mathrm{~m}$ の津波の場合を Fig. 3(b) に示 す。この場合は浸水は更に進み, 那賀川沿いには $750 \mathrm{~m}$ 以上の地点にまで達する. また海岸前面および北端の小 水路からの浸水によって, ほとんど町の集落全域が浸水 していることがわかる. 特に $H_{r}>1.5 \mathrm{~m}$ の面積の増加が 著しい.

一方防潮堤が建設された現状での津波の挙動を, Fig. 
Table 1. Reduction of the inundation area by the sea wall.

\begin{tabular}{|c|c|c|c|c|c|c|c|c|c|c|c|c|}
\hline \multirow{3}{*}{$\begin{array}{l}H_{0} \\
(\mathrm{~m})\end{array}$} & \multicolumn{9}{|c|}{ Inundation area } & \multicolumn{3}{|c|}{$\begin{array}{c}\text { Area of } \\
C^{2} \mathrm{H}_{\mathrm{r}}>8 \mathrm{~m}^{3} / \mathrm{s}^{2}\end{array}$} \\
\hline & \multicolumn{4}{|c|}{ Left bank } & \multicolumn{4}{|c|}{ Right bank } & \multirow{2}{*}{$\begin{array}{c}\text { Total } \\
\text { (ha) }\end{array}$} & \multirow{2}{*}{$\begin{array}{c}\text { Left } \\
\text { bank } \\
\text { (ha) }\end{array}$} & \multirow{2}{*}{$\begin{array}{l}\text { Right } \\
\text { bank } \\
\text { (ha) }\end{array}$} & \multirow{2}{*}{$\begin{array}{c}\text { Total } \\
\text { (ha) }\end{array}$} \\
\hline & $H_{r}>1.5$ & $\begin{array}{l}1.4> \\
H_{r}>0.5\end{array}$ & $H_{r}<0.4$ & Total & $H_{r}>1.5$ & $\begin{array}{l}1.4> \\
H_{r}>0.5\end{array}$ & $H_{r}<0.4$ & Total & & & & \\
\hline 4.33 & 0.85 & 0.97 & 0.92 & 0.92 & 0.57 & 0.44 & 0.62 & 0.53 & 0.69 & 0.74 & 0.59 & 0.67 \\
\hline 3.30 & 0.67 & 0.97 & 1.18 & 0.96 & 0.73 & 0.48 & 0.34 & 0.50 & 0.70 & 0.76 & 0.72 & 0.74 \\
\hline
\end{tabular}

$H_{0}$ : maximum heights of tsunami at the outer rim of the computation area.

$H_{r}$ : inundation heights above ground.

$C$ : current velocity of flooding water.

Table 2. Fault parameters of source models for the Sanriku tsunamis.

\begin{tabular}{llcccccccc}
\hline \hline & $M$ & $\begin{array}{c}\mathrm{L} \\
(\mathrm{km})\end{array}$ & $\begin{array}{c}W \\
(\mathrm{~km})\end{array}$ & $\begin{array}{c}\delta \\
\left({ }^{\circ}\right)\end{array}$ & $\begin{array}{c}{ }^{\theta} \\
\left({ }^{\circ}\right)\end{array}$ & $\begin{array}{c}U_{s} \\
(\mathrm{~m})\end{array}$ & $\begin{array}{c}U_{d} \\
(\mathrm{~m})\end{array}$ & $\begin{array}{c}M_{0} \\
(\mathrm{dyn} \cdot \mathrm{cm})\end{array}$ & $M_{w}$ \\
\hline $1933 \cdot 3 \cdot 3$ & 8.1 & 185 & 50 & 45 & $\mathrm{~N} 0 \mathrm{E}$ & 0 & 6.6 & $4.3 \times 10^{28}$ & 8.36 \\
$1896 \cdot 6 \cdot 15$ & $81 / 2$ & 210 & 50 & 20 & $\mathrm{~N} 24 \mathrm{E}$ & -6.7 & -10.6 & 5.9 & 8.45 \\
\hline
\end{tabular}

$M$, earthquake magnitude; $L$, fault length; $W$, width; $\delta$, dip angle; $\theta$, direction of strike; $U_{s}$, strike slip component (right rateral + ); $U_{d}$, dip slip component (normal + ); $M_{0}$, seismic moment; $M_{w}$, moment magnitude.

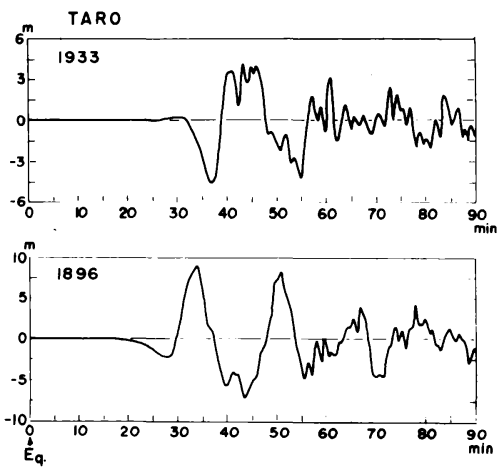

Fig. 4. Changes in the water levels at the outer rim of the area under computation. For the 1896 tsunami, the amplitude is multiplied by 0.78 .

3(c), (d) に $H_{0}$ が $3.3 \mathrm{~m}$ および $4.33 \mathrm{~m}$ の場合について示 してある. まず安政東海津波に相当する (c) を (a) とくら べてみると, 海岸および町北端部からの津波の浸水は, 完全に防止されていることがわかる. Fig. 2 を参照する と, ここは町の最も密集した集落のある部分で, 防潮堤 の効果か認められる. しかし河口部からの津波の侵入量 は意外に多く, 那賀川沿いの浸水域は, 防潮堤のない(a) に比べて僅かに減少している程度である. $H_{0}=4.33 \mathrm{~m}$ の場合の Fig. 3(d) でも, 海岸前面からの浸水は防潮堤 によって阻止されていて, 町の人家稠密な部分は浸水し ていない.しかし河口からの侵入は防潮堤のない場合と
の差が少く，また町の北端小水路からの浸水が，町の低 地にしみ出すように拡がっている.

以上の結果から, 那賀川の左岸と右岸にわけて, 地表 からの浸水高さ別の浸水面積，およびその浸水高さに流 速の 2 乗を乗じた積（水流の圧力を代表する）が $8 \mathrm{~m}^{3}$ / $\mathrm{s}^{2}$ 以上に達した部分の面積を, 防潮堤のない場合とある 場合とで比較した，防潮堤のあることによる面積の縮少 率を Table 1 に示す. 浸水域でみると, 那賀川左岸の縮 少率が僅かであるのに比べて, 右岸側はかなり縮少して いる. $H_{0}=3.3 \mathrm{~m}$ の場合の $H_{r}<0.4 \mathrm{~m}$ の面積は, 防潮堤 があると，ない場合に比べ約 $1 / 3$ になっている. 総浸水

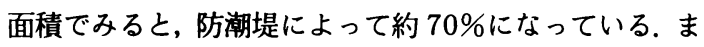
た家屋損壊が浸水家屋の $50 \%$ を越えるような $C^{2} H_{r}>8$ $\mathrm{m}^{3} / \mathrm{s}^{2}$ [相田 (1977a)] の面積は, $H_{0}=3.3 \mathrm{~m}$ のとき左岸 あ右岸もほぼ $70 \%$ 程度に減少している. しかし $H_{0}=$ $4.33 \mathrm{~m}$ では防潮堤後背地への浸水がないことにより右 岸の面積縮少率が 59\%になることがわかる.

\section{§4. 岩手県田老の婸合}

\section{1 実跧条件}

岩手県田老は, 1933 年および 1896 年の 2 度の三陸 大津波で大きな災害を被ったところであるが，それを教 訓に有名な大防潮堤が建設されている。 そこで検討の対 象をこの二つの津波とし, 波源は相田 (1977b) によって 求められているモデルを用いることにする（断層パラ 


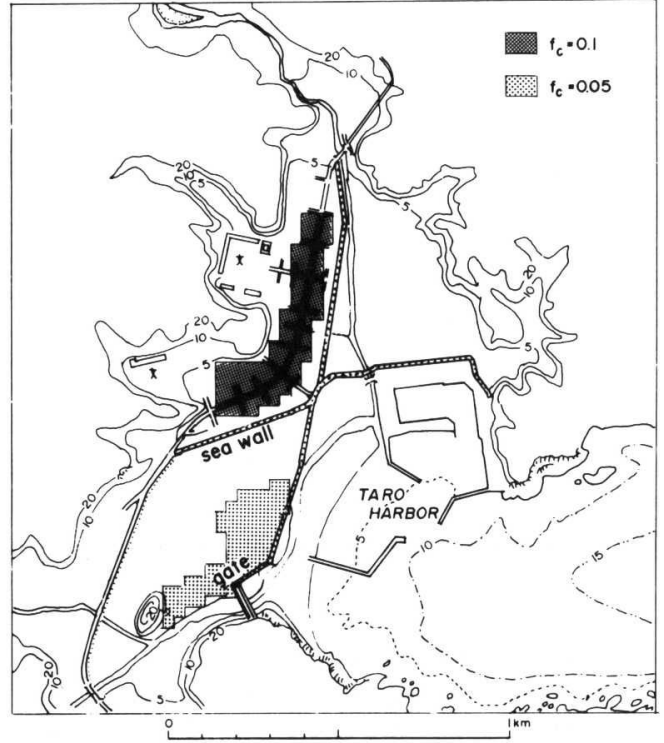

Fig. 5. Area for the inundation model at Taro, Iwate Prefecture. Effective friction coefficients $f_{c}$ are assumed 0.1 in the thickly shaded area, 0.05 in the thinly shaded area, and 0.01 in other areas, respectively.

メータは Table 2 参照). 外海計算格子は $5 \mathrm{~km}$ とし, 田 老近傍浅海域を $1 / 2$ づつ 4 段階に格子間隔を細かくし, 最終の間隔 $312.5 \mathrm{~m}$ の $7 \times 13$ 個の格子域外縁水位を, すべて一旦ディスクにファイルした，その代表点（水深 $29 \mathrm{~m}$ ）の波形を Fig. 4 に示す.

1933 年津波と 1896 年津波の特徵は, 1933 年の場合 の下げ波の大きいことであろう。この地震は正断層で あった [KANAMORI (1971)]ので, 海溝より陸側に大きい 沈降域を生じ，下げ波を発生したのである．それに対し て, 1896 年の地震は逆断層地震と考えられており [例 えば, 羽鳥(1974)]，そのため初め下げ波があらわれて はいるが，その大きさは上げ波に比較して小さい.

田老の津波遡上計算を行うために，格子間隔を更に 1/2の $156.25 \mathrm{~m}$ にして, この領域の外縁にさきにファ イルした津波水位を入力として与えた. 入力としてはこ の水位のみを与え, その他の条件は無視した. この領域 の奥に Fig. 5 で示す範囲を, 格子間隔が $31.25 \mathrm{~m}$ の浸 水モデルとして設定した。図中濃い影をつけた地域は, 人家が比較的集中している地域で，その部分には等価摩 擦係数 $f_{c}=0.1$ を与えた. つぎに薄い影をつけた地域は 防潮林であって， $f_{c}=0.05$ を与えた。その他の陸上部お よび $5 \mathrm{~m}$ 以浅の海底は $f_{c}=0.01$, 水深 $5 \mathrm{~m}$ 以上の海底 は $f_{c}=0.005$ を与えた.

また図中で，二重線に点を入れたものは津波防潮堤で

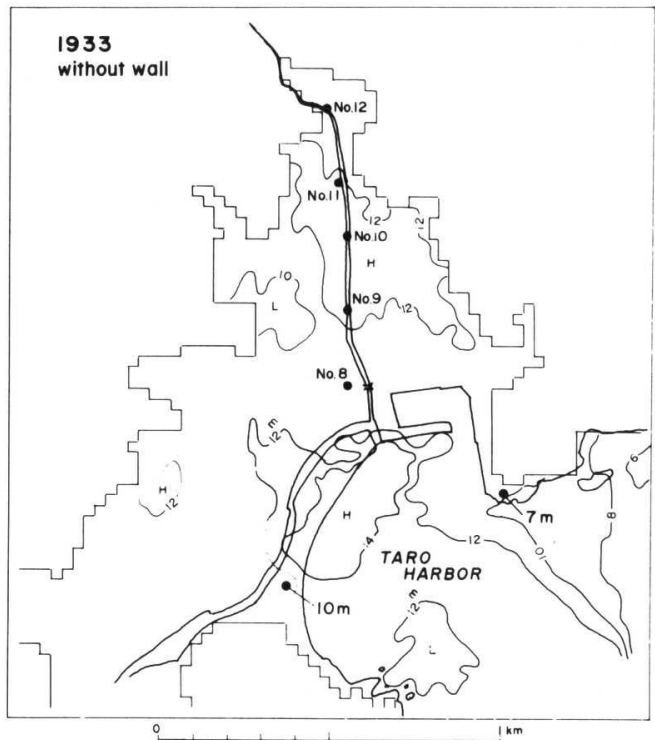

Fig. 6. Distribution of the maximum water rise above the still water level computed for the 1933 Sanriku tsunami assuming no wall. Solid circles and numerals indicate the observed spots and the tsunami height observed. Double circles with numbers are the points where the changes in water level with time are shown in Fig. 8.

あり，X字形に交わっている．これは北と西に延びるも のが初めに建設されたのであるが，その後居住区域の拡 大, 港の埋立などに伴い, 東および南に延びる防潮堤が 建設され，このような形となったあのである．高さはい ずれも T.P.上 $10 \mathrm{~m}$ となっている. 防潮堤西端から延び る道路は, 築堤になっているので, 計算上はこの部分も 防潮堤として取扱った。水深データは水路部発行の 1/ 50,000 海底地形図から読みとり, 田老港付近は「田老漁 港修築計画図」を参照した。 また陸上の標高は「1/5,000 北上山系開発調查図, 田老町」によった.

\subsection{3 年三陸津波}

まず 1933 年三陸津波の波形 (Fig. 4) を用いて, 防潮 堤を取除いた地形で計算を行った。 計算結果から静水面 上の最高水位の等高線を引いたものが Fig. 6 である.こ れによると海岸付近で $12 \mathrm{~m}$ 程度となっている. 当時の 調査報告 [地震研究所 (1934)] によると, その地図上に プロットされた津波の高さは Fig. 6 の黒丸で示した 10 $\mathrm{m}, 7 \mathrm{~m}$ となっている. 数值実験でも $12 \mathrm{~m}$ の等高線の西 側, 黒丸の $10 \mathrm{~m}$ 之記した地点のやや西では 10〜10.5 $\mathrm{m}$ 位の高さを示しており，この数值実験結果は実際津波 よりやや大き目の傾向があるものの, 1933 年津波の挙 動にかなり近似していると考えてよいと思われる. 


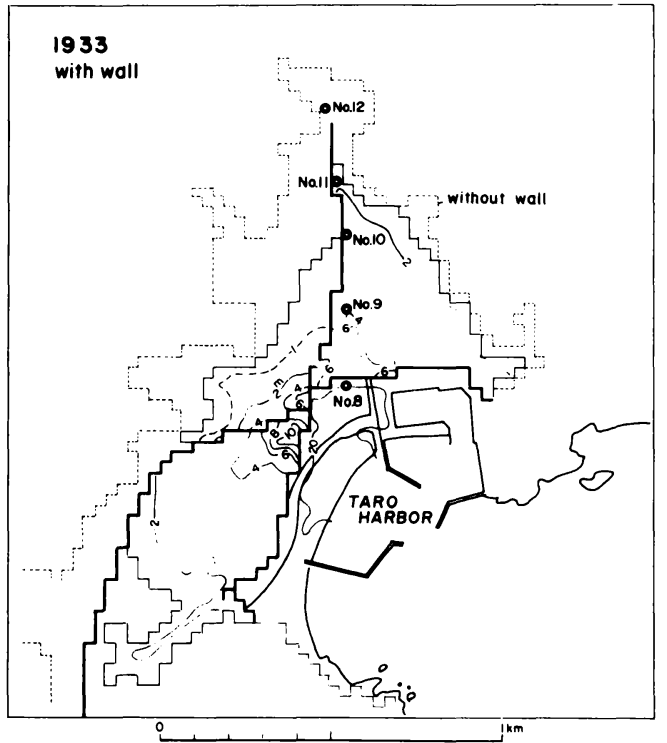

Fig. 7. Distribution of the maximum inundation heights above ground as computed for the 1933 Sanriku tsunami assuming the presence of the wall. The thick lines show the sea walls having a $10-\mathrm{m}$ height.

なお外周に屈曲した細線で描いたものは浸水域の境界 であって, Fig. 5 の地形からみるとほとんど標高 $10 \mathrm{~m}$ の線まで浸水していることがわかる.

つぎに高さ $10 \mathrm{~m}$ の防潮堤が建設された現状での数値 実験から，地表上の最高浸水高を Fig. 7 に示した。.太い 実線が防潮堤をあらわす。防潮堤外側の水位が, 防潮堤 のなかった場合よりかなり上昇し，局部的・瞬時的には $20 \mathrm{~m}$ にも達する. したがって $10 \mathrm{~m}$ の防潮堤を乗り越 えて堤内に浸水し, 浸水高の高い所は, 新旧防潮堤の交 叉する内側部分で, 部分的に $6 \mathrm{~m}$ 以上になっており, 全 体としても $2 \mathrm{~m}$ 程度浸水することになる. 旧防潮堤の内 側は，新防潮堤之交わって堤体が一つになっている部分 のみ, 局部的に 4 6 $\mathrm{m}$ の高さの浸水があるが, その他 は $2 \mathrm{~m}$ 以下で面積もせまい. この場合の浸水域は, 細い 実線の屈曲線で示してあるが, 点線で示した防潮堤のな い場合の浸水域と比べて, とくに旧防潮堤内側で狭く なっていることがわかる.

Fig. 6 に番号 (No. 8〜12) を付して示した二重丸の地 点の浸水水位の時間的変化を, Fig. 8(a) に防潮堤のある 場合, (b)に防潮堤のない場合についてプロットした. 新 防潮堤直前の No. 8 の水位を比較すると, 防潮堤のない 場合最高約 $10 \mathrm{~m}$ であるが, 防潮堤のある場合は最高 15 $\mathrm{m}$ に達し, 数回にわたって防潮堤高さ $10 \mathrm{~m}$ を越えてい る. しかし新・旧防潮堤にはさまれた地域の No. 9, 10

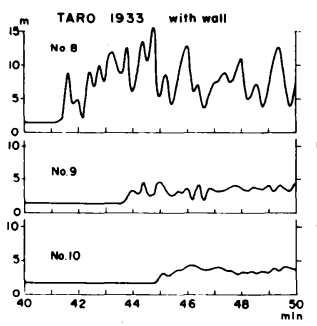

(a)

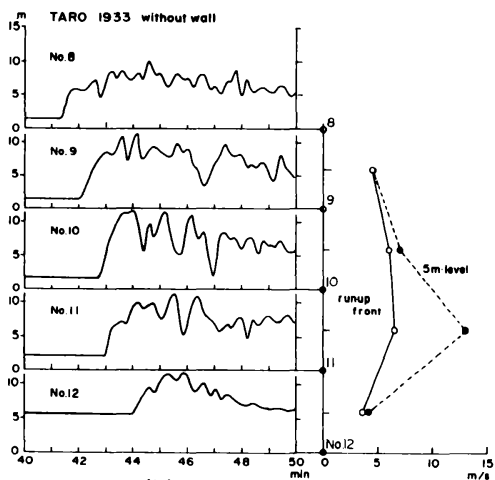

(b)

(c)

Fig. 8. Changes in water level with time at the various spots denoted by the numbers in Fig. 6. (a) with the walls; (b) without the walls; (c) open circles show the speed of the wave front proceeding between two neighboring spots, solid circles the speed of water wall in front of the tsunami.

では，防潮堤のない場合より水位は当然低くなり，時間 的にあかなり遅れている. No. 11, No. 12 地点には浸水 していない，たとえ津波が防潮堤を乗り越える場合で あ, 浸水の状況はかなりゆるやかになるから, 被害の程 度は軽減されるであろう。

1933 年津波の際に，津波に先立って突風を感じたと いう記録がある. 地震研究所（1934）の報告の田老村の 項に,「風起って浪に先立って家が倒れたという」,「1秒 10 米位の早さにて山上の木々を吹く暴風の如き音を 立って来れりと云ふ」といった記事がみられる。このよ うな風が起る機構を考えてみる. Fig. 8(b) から津波が上 陸して先端の移動する速さを求めてみると，(c)に白丸 でプロットしたように 4 $6 \mathrm{~m} / \mathrm{s}$ 程度である. しかし (b) の波の前面の形をみると, 次第に前面が急峻になっ てきており, 例えば $5 \mathrm{~m}$ のレベルの位置で前面の水の壁 の進む速さを求めると, No. 10 から No. 11 の間で 13 $\mathrm{m} / \mathrm{s}$ 程度の速さが得られる。これを(c)に黒丸でプロッ トしたが，この程度の速さなら，家が倒れるのは別とし $\tau$, 前記の “1 秒 10 米位の早さ” の風というのはあり得 そうである. ことに No. 10,11 のあたりになると, 東西 に高所がせまって来るので, 一層風を誘起し易くなると 思われる.

\subsection{6 年三陸津波}

つぎに 1896 年津波に対して Fig. 4 の波形を入力して みると, 実験結果はやや大きくなり過ぎた。そこで入力 を 0.78 倍してみると, 伊木 (1897)による実測津波高さ $14.6 \mathrm{~m}$ にほぼ見合った結果が得られた。.この入力で防 潮堤のある場合の数値実験から, 地表上の最高浸水高さ 
の分布を Fig. 9 に示す. 防潮堤外では 1933 年津波の場 合之同様 $20 \mathrm{~m}$ 以上の高さに達しておら, 防潮堤の高さ を越えている. したがって防潮堤内への浸水により, 新・旧防潮堤にはさまれた領域では, ほとんど全面にわ たって浸水, 高さむ $2 \mathrm{~m}$ 以上になる.ことに防潮堤が交 叉するあたりでは, 8〜 $10 \mathrm{~m}$ に達する部分もある.

しかし旧防潮堤の内側では, 浸水は $2 \mathrm{~m}$ 以下が大部分 で, 面積も限られている. Fig. 9 に細い実線で示した屈 曲線は浸水域の外縁を示すが, 点線で示した防潮堤のな い場合のそれと比較するとそれは明瞭である.

1933 年津波前面の風圧について先に言及したが,

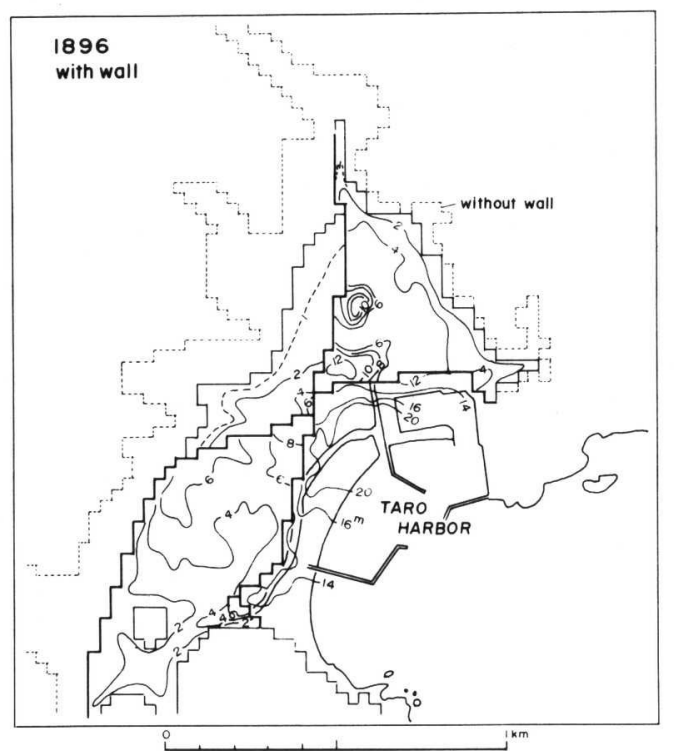

Fig. 9. Distribution of the maximum inundation heights above ground computed for the 1896 Sanriku tsunami assuming the presence of wall.
1896 年津波の場合の波先端の壁の見かけの速さは, No. 10 と No. 11 の間で $26 \mathrm{~m} / \mathrm{s}$ 程度になり, 大津波のとき かなりの風圧が発生する可能性を示唆している.

\section{4 浸水と被害}

前述のように, 防潮堤を越える津波が来襲すれば, 浸 水被害を生じるが, 単に浸水のみに止まるか, 家屋・構 造物の破壊に至るかは, 津波の流れの速さに強く依存し ている.これをあらわす指標として，\$3で既に述べた， 流速の 2 乗と地上浸水高さの積 $C^{2} H_{r}$ が $8 \mathrm{~m}^{3} / \mathrm{s}^{2}$ 以上の 部分を斜線で影をつけて示したものが Fig. 10 で, 左は 1933 年津波, 右は 1986 年津波である. 田老の場合この 値が実に $100 \mathrm{~m}^{3} / \mathrm{s}^{2}$ を超える地域むかなりあり,これを 二重斜線で影をつけて示した. 図をみると新・旧防潮堤 にはさまれた地域に, かなり広く拡がっている. $8 \mathrm{~m}^{3} / \mathrm{s}^{2}$ 以上の範囲は, 1896 年津波の場合ほとんど浸水域全域 である.

$100 \mathrm{~m}^{3} / \mathrm{s}^{2}$ を超える地域は Fig. 9 からみると, 地上の 浸水高 $4 \mathrm{~m}$ 以上の地域に相当しており, したがって流速 は $5 \mathrm{~m} / \mathrm{s}$ 程度と考えられる. 津波による家屋破壊の機構 としては, 波圧による衝撃的な破壊も大きなものと思わ れるが, 人家のこみ入った場所などでは, 流体の流れに よる圧力の効果も大きな要因と思われる. 流体の流れに よる圧力は, 本質的に密度と流速の 2 乗の積に比例する から, 水流 $5 \mathrm{~m} / \mathrm{s}$ は $140 \mathrm{~m} / \mathrm{s}$ の風速にあたることにな り，木造家屋が完全に破壊されるだろうことは想像に難 くない. 羽鳥 (1984) は $C^{2} H_{r} \fallingdotseq 100 \mathrm{~m}^{3} / \mathrm{s}^{2}$ で家屋の破壊 率が $100 \%$ に達するとしている. 彼の $C$ の求め方は, 数 值実験とは異り直ちに比較は出来ないが, 破壊率の高さ を共に示すといえよう.

しかし旧防潮堤内側は浸水はあっても破壊は少く，か なり安全ということが出来よう. 田老の場合, 町の発展 と共に旧防潮堤の外に新防潮堤が建設され，たまたま二

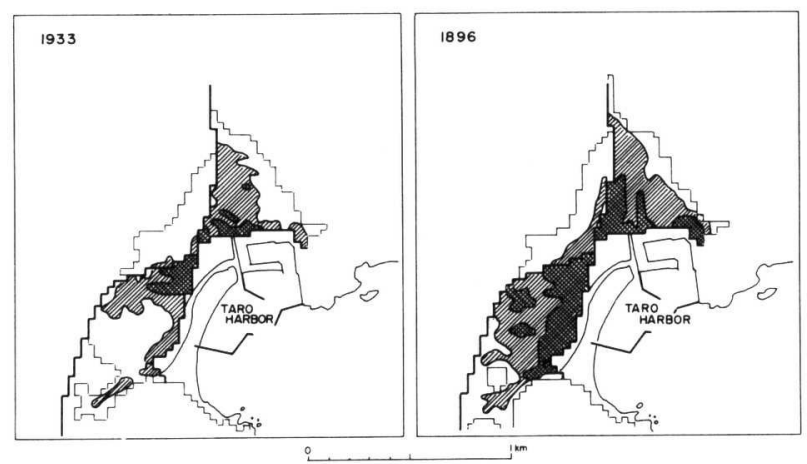

Fig. 10. Distribution of the representative hydraulic pressure which is expressed by the product of the square of water velocity and inundation height above ground. Thickly and thinly hatched areas indicate the regions where hydraulic pressure become more than $100 \mathrm{~m}^{3} / \mathrm{s}^{2}$ and $8 \mathrm{~m}^{3} / \mathrm{s}^{2}$, respectively. 
重構造になったものであるが, それが旧防潮堤内側の安 全性には重要な役割を果している.

\section{§5.むすび}

津波対策として建設された防潮堤に，設計高さより高 い津波が来襲した場合の挙動を検討した。 その結果をま とめるとつぎのようである.

(1) 河口あるいは港口に防潮水門が無い場合は, そこ からの津波の侵入が大きい.

(2) 過去の津波の高さで防潮堤の高さが決められてい ると, その高さの津波が来襲した場合, 防潮堤外直前で は反射の影響で水位が高くなり, 津波は防潮堤を越え る.

(3) 防潮堤を越えた場合，すぐ内側の地域はかなりの 浸水高さと速い水流の影響を受け，家屋などが破壊され る危険性がある。

(4) 来襲する津波の高さが，防潮堤を越えないことが 確かでない限り, 高所へ避難することが必要である. 防 潮堤があることによる安心感から避難を軽視するような ことがあれば, 非常に危険な事態を招くおそれがある.

\section{謝辞}

現地地形や防潮堤に関するデータの提供を頂いた, 静 岡県および田老町御当局に感謝の意を表する.

\section{文献}

相田 勇, 1977a, 陸上に溢れる津波の数値実験一高 知県須崎および宇佐の場合, 地震研究所曼報, $\mathbf{5 2}$, 441-460.

相田 勇, 1977b, 三陸沖の古い津波のシミュレーショ ン, 地震研究所盘報, 52,71-101.

相田 勇, 1981, 東海道沖におこった歴史津波の数値実 験, 地震研究所量報, 56, 367-390.

相田 勇・羽鳥徳太郎, 1982, 尾熟市街に遡上した津波 の数値実験, 地震研究所菓報, 57, 337-350.

土木学会, 1971 , 水理公式集, 土木学会, 265pp.

後藤智明, 1986, 津波数值計算, 1986 年度（第 22 回） 水工学に関する夏期研修会講義集 B コース, 土木学会 水理委員会, B-3-1 B-3-21.

羽鳥徳太郎, 1974, 東北日本太平洋側における津波の波 源, 地震 2, 27, 321-337.

羽鳥徳太郎, 1977, 静岡県沿岸における宝永・安政東海 地震の津波調查, 地震研究所亩報, 52, 407-439.

羽鳥徳太郎, 1984, 津波による家屋の破壊率, 地震研究 所彙報, 59, 433-439.

伊木常誠, 1897, 三陸地方津波実況取調報告, 震災予防 調查会報告, $11,5-34$.

岩崎敏夫・真野 明・荒井 唯, 1981, 綾里湊における 津波の数値解析, 第 28 回海岸工学講演会論文集, 土 木学会, 79-83.

地震研究所, 1934 , 昭和 8 年 3 月 3 日三陸地方津波に 関する論文及報告, 地震研究所異報別冊, 1 号, 第 2 編報告, 250pp.

Kanamori, H., 1971, Seismological evidence for a lithospheric normal faulting-the Sanriku Earthquake of 1933, Phys. Earth Planet. Interiors, 4, 289-300. 